\title{
MINERAL RADIOACTIVITY IN SANDS AS A MECHANISM FOR FIXATION OF ORGANIC CARBON ON THE EARLY EARTH
}

\author{
JOHN PARNELL \\ Department of Geology and Petroleum Geology, University of Aberdeen, Aberdeen AB24 3UE, U.K. \\ (for correspondence, e-mail: J.Parnell@abdn.ac.uk, fax: +44 122427 2785)
}

(Received 3 November 2002; accepted in revised form 30 July 2003)

\begin{abstract}
Irradiation of organic molecules by mineral radioactivity is a feasible alternative to cosmic irradiation to precipitate solid organic carbon-rich matter on the early Earth. Radioactive (uranium- and thorium-rich) minerals have been concentrated at the Earth's surface, and accumulated accretionary coatings of carbon due to irradiation, since early Archean times. The organic accretion process could have occurred at the surface or in the sub-surface, and is independent of a terrestrial or extraterrestrial source for the carbon.
\end{abstract}

Keywords: early Earth, habitable zones, irradiation, monazite, polymerization, rocky planets

\section{Introduction}

The field of radiation chemistry is based upon the influence of irradiation on bonds in organic molecules, which are broken and reformed to build new, and often larger, molecules (Charlesby, 1987; Spinks and Woods, 1990). While most of our knowledge of radiation chemistry comes from industrial syntheses, it is clear that irradiation also plays a role in the formation of organic molecules in nature. Cosmic irradiation causes organic chemical reactions in interstellar clouds (Ehrenfreund et al., 2002; Bernstein et al., 2002), and within our solar system on icy planets and their moons (McCord et al., 1997; Strazzulla et al., 1984; Chyba and Phillips, 2001). Similarly, laboratory experiments on simulated astrophysical ices show that methane, carbon monoxide and carbon dioxide can be converted to alcohols, formaldehyde and long-chain polymers (Bernstein et al., 1997, 1999; Strazzulla and Palumbo, 1998). Some of these irradiation reaction products may even be solids (e.g. Khare et al., 1987). However, in addition to the ultraviolet irradiation encountered in these extraterrestrial environments, on rocky planets such as Earth mineral radioactivity is an alternative source for the precipitation and concentration of organic molecules.

Crustal radioactivity has been considered 'probably not an important energy source for the synthesis of organic compounds on the primitive Earth' (Miller et al., 1976). However, like cosmic irradiation, energetic particles from heavy radioelements (uranium, thorium) can cause the polymerisation of organic molecules. This type of irradiation should be more locally effective, as energetic particles in solids 


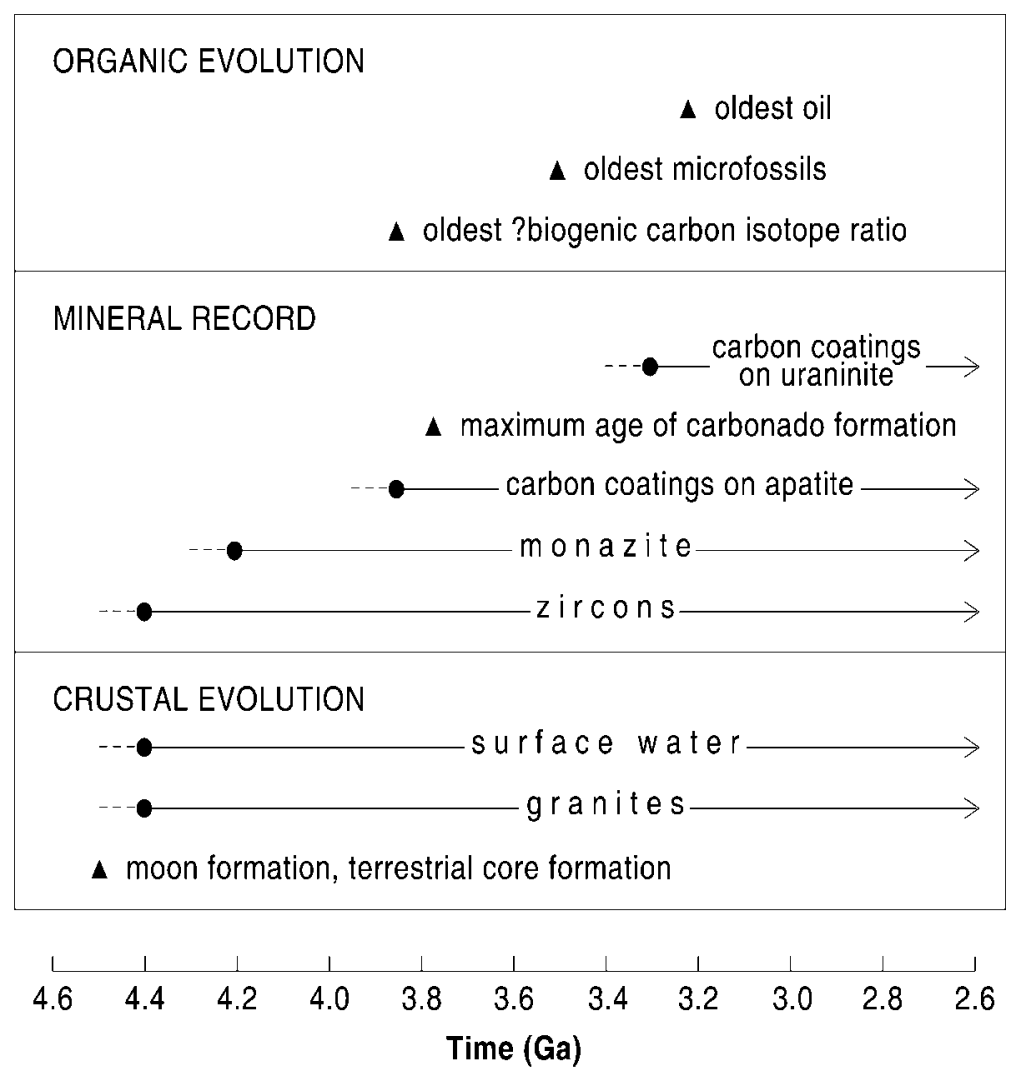

Figure 1. Early Precambrian record of crustal evolution, radioactive minerals, and organic evolution (data from Wilde et al., 2001; Peck et al., 2001; Maas et al., 1992; Saager et al., 1982; Mojzsis et al., 1996; Ozima and Tatsumoto, 1997; Rasmussen and Buick, 2000). Radioactive minerals predate oldest evidence for life.

are focussed along linear tracks, and the recombination of molecular fragments is easier in solids and liquids than in gases (Spinks and Woods, 1990). There is evidence in the geological record that crustal radioactivity has caused precipitation. Where uranium/thorium are concentrated in minerals, they can be templates for the precipitation of complex organic products, evidenced by carbonaceous coatings accreted around grains of uraninite, thorium-rich monazite, uranium-rich zircon, uranium-rich apatite, and other minerals (see below).

Recent evidence for zircon crystals, and water at the planetary surface at a time prior to the record of life (Figure 1) (Wilde et al., 2001; Peck et al., 2001, Valley et al., 2002), invite a reassessment of the potential of mineral radioactivity to promote organic fixation on the early Earth. 


\section{Radioactive Mineral Sands}

Radioelements were readily concentrated at the Earth's surface during the Hadean and Archean. The oldest zircons indicate the production of granitic magma at 4.4Ga (Wilde et al., 2001; Peck et al., 2001) (Figure 1). Isotope data from these zircons indicate that there were surface waters at this time (Wilde et al., 2001; Peck et al., 2001, Valley et al., 2002). Zircons, monazites and other heavy minerals were liberated into surface sediments by erosion of plutonic hinterlands. Monazite inclusions in early zircons date this mineral back to at least $4.2 \mathrm{Ga}$ (Maas et al., 1992). These uranium/thorium-bearing phases would have been concentrated at the surface by the same waters that could be the medium for introducing organic molecules. Their high density means that the minerals are particularly susceptible to hydrodynamic sorting by moving water (rivers, tidal flow, wave action) and also by wind action. The sorting of heavy minerals in standing water bodies was enhanced by tidal motion induced by the presence of a moon, and they form concentrations in early Archean sediments (Maas and McCulloch, 1991) and throughout subsequent geological history. Hence, for example, they can form accumulations in beach strand lines at the margins of oceans, shallow seas and lakes. At the present planetary surface, radioactive monazite sands are concentrated at the margins of each of the large oceans, e.g. in Brazil (Malanca et al., 1995, 1998), Vietnam (Hung et al., 1993), Australia, and India (Ali et al., 2001), and also around lakes, e.g. Issyk-Kol in Central Asia (Hamby and Tynybekov, 2002), and fluvial systems, e.g. the Nile Delta (Gindy, 1961). Commonly the radioactive sands are conspicuously black in colour, due to accompanying concentrations of heavy, iron-bearing minerals such as ilmenite and magnetite. Monazite sands represent the most radioactive sedimentary deposits at the Earth's surface today, with effective dose rates up to 270 $\mathrm{mSv} / \mathrm{yr}$, about 650 times the world average value (Malanca et al., 1995; Eisenbud and Gesell, 1997). They are sufficiently widespread to represent a globally significant source of high-dose irradiation. The strand-lines of heavy mineral sands extend for up to hundreds of kilometres: Indian beaches alone contain 8 million tonnes of monazite (Ali et al., 2001). In the first half of Earth's history before the atmosphere became significantly oxygenated (Levine et al., 1982; Walker, 1985), uraniniterich sands would also have been stable at the surface (Simpson and Bowles, 1981). Uraninite was a source of exceptionally high irradiation dose due to a very high uranium content; much higher than in the monazite-rich and zircon-rich sands of today. The Archean Witwatersrand uranium-gold deposits have a multi-stage genesis but appear to have started by accumulation of extensive hydrodynamic accumulations of uraninite grains in a fluviodeltaic environment (Robb et al., 1997). Uraninite is unstable in oxidizing conditions, so is rare at the Earth's surface today, but nevertheless is found in some sands (Coppens and Mayanda, 1969; Simpson and Bowles, 1981).

The closer proximity of the moon during early Earth history would have made tidal sorting of grains to concentrate heavy minerals even more effective than today. 


\section{Precipitation around Radioactive Grains in the Geological Record}

The geological record includes widespread evidence for organic accretion and precipitation around radioactive mineral grains (Figures 2 and 3). In most cases this involved the accretion of hydrocarbon fluids that encountered the grains in the sub-surface (i.e. the starting material was already complex, derived from biogenic organic matter). The record includes accretions around uraninite grains in Archean sedimentary rocks, including substantial carbonaceous deposition in the Witwatersrand uranium deposits (Buick et al., 1998), thorite and thoriferous monazite grains in Phanerozoic sandstones (Rasmussen et al., 1989; Glover, 1992), and zircon grains in Precambrian gneisses (Parnell, 1996a). The oldest recorded accretions around uraninite are in the Swaziland Supergroup in southern Africa (Saager et al., 1982) at $3.3 \mathrm{Ga}$ or older (Figure 1). Carbonaceous coatings are also recorded around uranium-bearing apatite grains in the early Archean of the $>3.85$ Ga Akilia Island metasediments, Greenland (Mojzsis et al., 1996), although an origin for these coatings by irradiation has not been assessed and there is debate about whether this carbon is of biogenic origin (Manning et al., 2001; Fedo and Whitehouse, 2002; Ueno et al., 2002) and its time of formation (van Zuilen et al., 2002). The record clearly extends back through most of Earth's history, comparable to the time frame which yields evidence for life (Figure 1). An example showing how carbonaceous coatings occur particularly around heavy mineral concentrations in shallow marine sands, from the margin of the Llandovery (Silurian) sea in Wales, exhibits bedding surfaces studded with numerous carbon-coated monazite and thorite grains (Figure 2; Parnell et al., 1990).

Accretion of organic matter also occurs by the mixing of organic-bearing and radioelement-bearing fluids, within hydrothermal systems or aquifers: The reducing environment created by organic matter causes the precipitation of many metals, including uranium. Uranium is mobile (soluble in water) under oxidizing conditions (high Eh) but precipitates under reducing conditions (low Eh) such as are induced by the presence of organic matter (Parnell, 1988). Such precipitation concomitantly causes organic accretion due to irradiation. There are several examples of this in the Precambrian record, including the Oklo natural fission reactors, Gabon (Parnell, 1996b), and deposits in the basement terranes of North America (Landais et al., 1993).

Although all of these examples were accreted from a feedstock of complex molecules rather than simple compounds, they serve to show (i) that natural mineral grains have the potential to precipitate organic matter, and (ii) that this has been occurring on the Earth since Archean times. Some examples from the geological record do suggest precipitation from methane rather than from complex biogenic hydrocarbons: Carbonaceous matter accreted around uraninite in the Proterozoic of Saskatchewan and the Archean Witwatersrand deposits (Figure 3C) is attributed to this process (Liebenberg, 1955; Landais et al., 1993), supported by comparable isotopic compositions for carbon and methane samples at the same site (Landais 


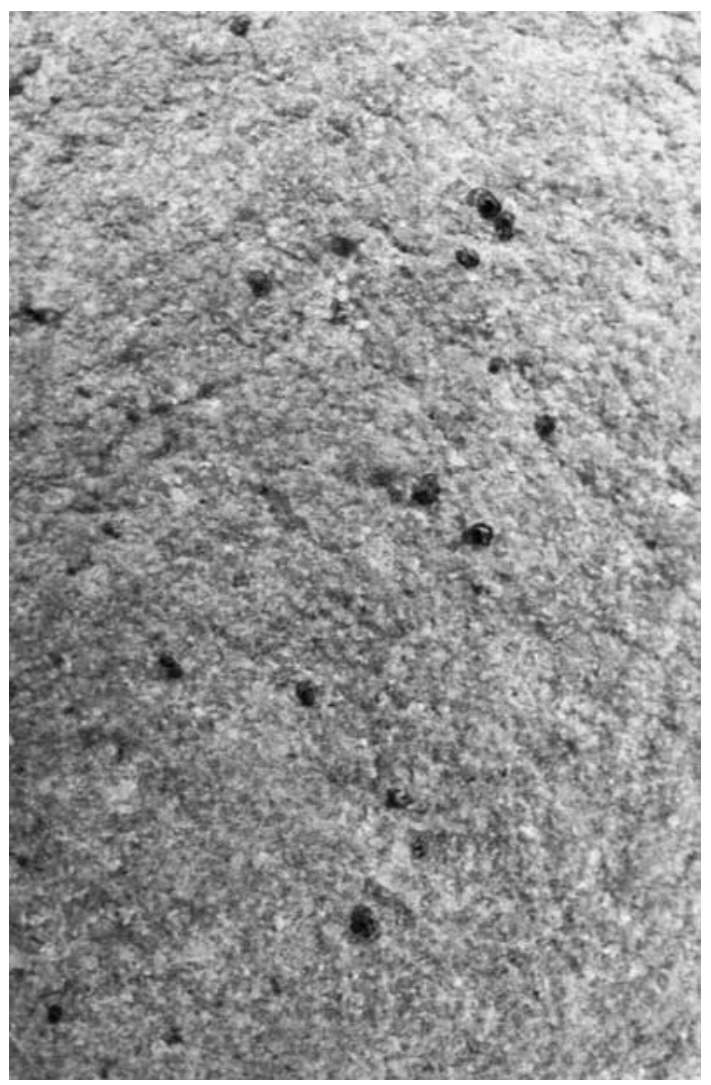

Figure 2. Bedding surface of shallow marine sandstone, showing numerous monazite and thorite grains coated with (black) carbonaceous matter due to mineral radioactivity. Silurian, Wales, field width $2 \mathrm{~cm}$.

et al., 1993). Laboratory experiments similarly show that the irradiation of methane by alpha-radiation can produce viscous liquid-solid polymers (Colombo et al., 1964).

The viability of radioactive grain accumulations as a setting for organic fixation is further evidenced by demonstration of (i) a role in precipitating organic molecules, and (ii) interaction in the vicinity of fluid conduits. The monazite grain in Figure 3A exhibits an accreted solid carbonaceous coating in a sandstone that has a bulk carbon content of only $0.1 \%$ : accretion has clearly caused carbon concentration above normal levels. The zircon grain in Figure 3B has caused similar accretion in a low-permeability Precambrian gneiss where fluid ingress was facilitated by cross-cutting fractures (Parnell, 1996a), indicating that mineral radioactivity could be a model for interaction involving organic molecules such as methane diffusing through rock in the Earth's subsurface, as well as molecules in surface waters. Examples of carbonaceous coatings around radioactive crystals in granites (Robb et al., 1994, McCready et al., 2003) similarly show that this process 

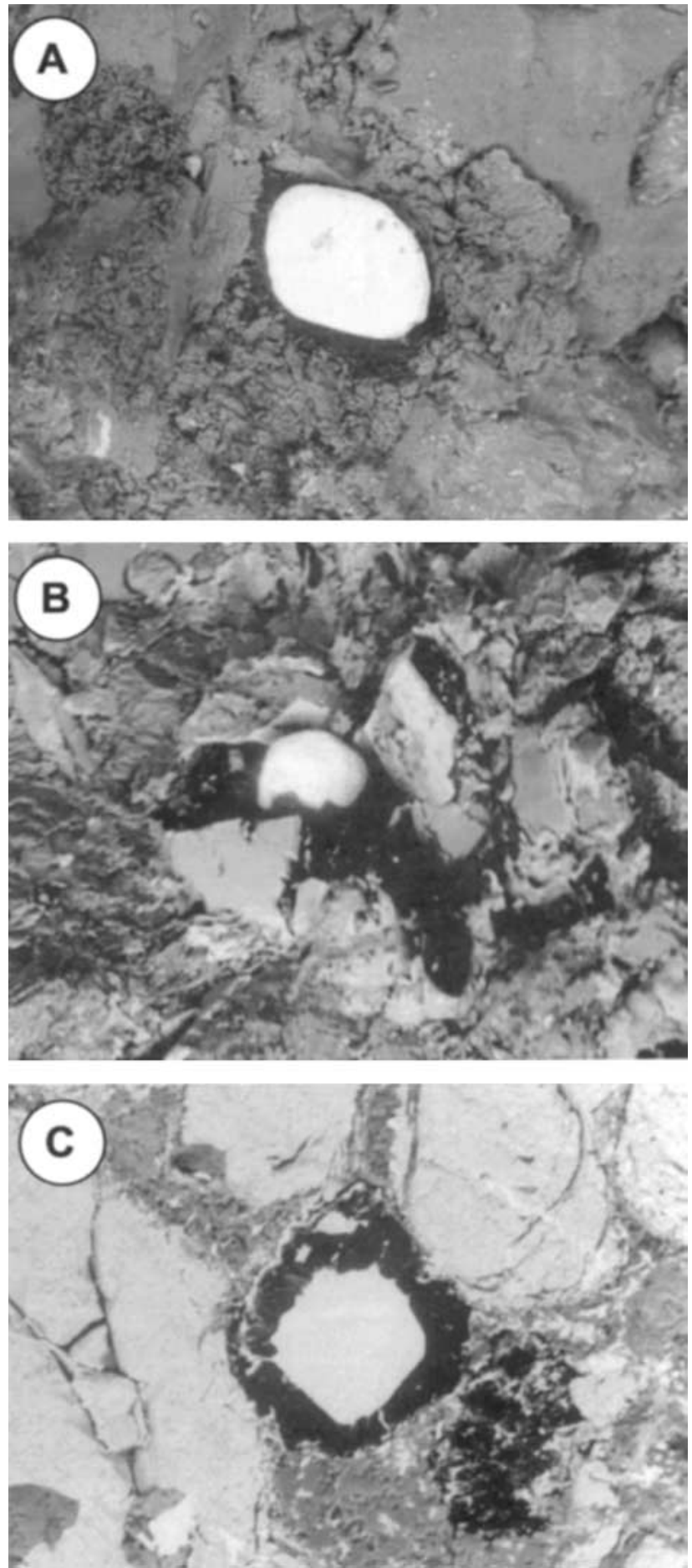

Figure 3. Radioactive mineral grains (bright) exhibiting accretionary carbon coatings (black). A: coating around monazite, Carboniferous sandstone, Lancashire, U.K. B: coating around zircon, Proterozoic gneiss, Ross-shire, U.K. C: coating around uraninite, Archean conglomerate, Witwatersrand, South Africa. Backscattered electron images, field widths 200 microns. 
occurs in the subsurface. Thus irradiation may be an important mechanism for the concentration of carbonaceous material within fracture systems in the crust. The volume of carbon accreted around a monazite grain ranges up to $60 \%$ of the grain volume. In heavy mineral sands rich in monazite, where a $10 \%$ monazite content is not uncommon, this equates to masses up to $70 \mathrm{~kg}$ carbon sequestered per cubic metre of rock. Even at much lower monazite contents and more limited accretion volumes, significant sequestration rates are possible.

\section{Discussion}

\subsection{SOURCES OF CARBON AND ENVIRONMENTS ON THE EARLY EARTH}

The early Earth received a high flux of organic molecules from extraterrestrial sources (Chyba and Sagan, 1992) that may have been photo-polymerized to a liquid organic layer at the oceanic surface (Lasaga et al., 1971; Nilson, 2002). Additionally methane from the mantle vented at the surface, concentrated in hydrothermal systems (Kelley, 1996; Holm and Charlou, 2001) and may have contributed to the formation of hydrocarbon liquids or smogs in the atmosphere (Sagan and Chyba, 1997). These accumulations of organic compounds at the surface could have been precipitated by interaction with radioactive grain accumulations. Even dissolved bicarbonate ions in sea water may have been irradiated to produce organic carbon compounds such as organic acids, formaldehyde and methanol, as this can be demonstrated experimentally, both by self-irradiation from carbon-14 in the bicarbonate and by irradiation from external sources (Albarrán et al., 1987; Albarrán and Collins, 1998). The record of limestones back to the early Archean (Nutman et al., 1984) shows that sea water was bicarbonate-saturated. Radioactive grain concentrations in beaches at the sea margins were the most likely sites for this process.

Such interactions would have been more effective during permeation into the subsurface, as exposure of organics to grains at the sediment surface is transient, and coated grains are not seen on modern beaches. Nevertheless, such sands are capable of inducing changes on a relatively short time scale, as evidenced by an increased incidence of chromosomal abnormalities in human populations living in the vicinity of monazite beach sands in China (Jiang et al., 2000) and India (Forster et al., 2002). This effect is a consequence of emanated, dispersed radon, so an even briefer response time is expected for organic molecules in direct contact with the grains, and it is feasible that at least the first layers of molecules to accrete on the grains did so on the beaches of early Earth. 


\subsection{COMPOSITION OF IRRADIATED ORGANIC MATTER}

The irradiation of organic matter on grain surfaces over a geological timescale produces an insoluble, refractory residue, but before this occurs modified organic molecules may still have a chance of mobility away from the grains. Detailed organic geochemical data for accreted carbon is limited, but work on the Oklo material shows it to include polycyclic aromatic hydrocarbons (PAHs) (Rigali and Nagy, 1997). Laboratory studies show that irradiation of hydrocarbons causes the breakage of C-H bonds to yield hydrogen, and carbon which cross-links to other molecules. Where the irradiation dose is high enough, completely insoluble polymers form. Although this represents a concentration of carbon, it has negligible potential for further reaction. However, in laboratory experiments at more moderate doses there remains a component that is soluble, mobile, and thus susceptible to chemical reaction (Colombo et al., 1964; Charlesby, 1987). Similarly, gas chromatography data from natural organic coatings around monazite grains confirm that some soluble compounds survive, including long-chain molecules (Rasmussen et al., 1989), which are available for further chemical reaction.

A distinctive feature of the chemistry of naturally irradiated organic compounds is their incorporation of oxygen. An enrichment in oxygen is a common characteristic of organic materials from uranium deposits (e.g. Penkov, 1980; Bonnamy et al., 1982). In some cases this may be due to reduction of mobile oxygenated uranium complexes, but the radiolysis of water can also yield oxidizing radicals that can be incorporated into organic materials (Landais et al., 1987; Forbes et al., 1988).

\subsection{THE IMPORTANCE OF GRAIN SURFACES}

This mechanism for fixing and concentrating carbonaceous material has the intrinsic advantage that it involves precipitation on a mineral surface, as such surfaces may promote polymer formation (Smith et al., 1999). Although heavy organic compounds have been formed by the irradiation of methane in the laboratory, it has been assumed that the dose rates and carbon concentration required for this to occur are greater than was present on the early Earth, so radioactivity has been considered insignificant as an energy source (Miller and Urey, 1959): The concentrations of radioactive grains provide both a high dose rate and a concentrating mechanism, i.e. the presence of a surface. Tidally-influenced shallow seas, where heavy minerals are most concentrated, are specifically suggested as sites for interaction between dispersed/dissolved organic molecules and mineral templates (Heckl, 2002). Mineral grain surfaces also have the advantage of presenting a large surface area for irradiation of the immediately surrounding environment. Experiments comparing the effect of irradiation on organic compounds involving and free from grain surfaces show that the mineral templates have a significant influence on the type of product (Caffrey and Allen, 1958; Colombo et al., 1964). This aspect requires fur- 
ther investigation, but emphasizes the potential for mineral substrates to influence the composition of organic matter.

\subsection{CARBonados}

A more extreme consequence of the irradiation from uranium/thorium could be the formation of carbonados, aggregates of micro-diamonds (Daulton and Ozima, 1996). Modelling of data from carbonados in Central Africa indicate a maximum age of formation of $3.8 \mathrm{Ga}$ (Figure 1) (Ozima and Tatsumoto, 1997). The formation of nanodiamonds in meteorites could be the ultimate result of either ultraviolet irradiation or high-energy particles (Nuth and Allen, 1992; Ozima and Tatsumoto, 1997), further emphasizing that irradiation from radioelements may make an important contribution to the precipitation of organic materials.

\section{The Potential for Irradiation on Other Rocky Planets}

The evidence for granitic rocks with zircons and monazites, and surface water, several hundred million years before the first evidence for life (Wilde et al., 2001; Peck et al., 2001) indicates that an environment for interaction with radioactive minerals was probably ready for the influx of organic molecules that underwent prebiotic chemistry on Earth. More generally, radioactivity is a viable mechanism for the fixation of organic carbon on other rocky planets. The availability of uranium/thorium at an adequate level requires their concentration in the crust. On Earth, these elements are not readily incorporated into high-pressure minerals that form in deep magmas, so they precipitate in the crust. The SNC meteorites from Mars have mineral assemblages that also suggest high-pressure magmatic processes (Frankel, 1996), implying that radioelements are similarly concentrated at shallower levels. Uranium and thorium contents in Martian meteorites are lower than in Earth crust samples (Mileikowsky et al., 2000), but the meteorites do not represent the rock types in which radioactive minerals become concentrated: a random sampling of twenty rocks from the Earth's crust would probably also show no evidence for uranium or thorium concentration. Gamma-ray spectrometry data from Phobos 2 (McLennan, 2001) and Mars Odyssey (Taylor et al., 2003) indicate higher levels in Martian soils than recorded in the meteorites, but still at lower concentrations than on Earth. Nevertheless, evidence for working of surface detritus by water on Mars (Malin and Edgett, 2000) suggests that concentrations of radioactive mineral grains are a possibility. As bicarbonate was probably the dominant anion in water on early Mars (Catling, 1999), it could have contributed to the formation of organic molecules through irradiation as discussed above.

Of wider significance, mineral radioactivity will also be evident on planets in interstellar space, for which long-lived radionuclides provide the necessary heat, and surface water oceans are feasible (Stevenson, 1999). Potentially these planets could 
represent the predominant residence for life in the Universe (Stevenson, 1999), and the radioactivity would be a ready mechanism to support the fixation of organic carbon. If irradiation is a viable alternative to photosynthesis in supplying energy for prebiotic synthesis and subsequent life (Chyba, 2000; Cooper et al., 2001; Garzón and Garzón, 2001), the distribution of rocky planets may substantially enlarge the habitable zone around stars.

A more conservative analysis might suggest that Earth is quite exceptional among rocky planets, in that the surface concentration of radioactive minerals is favoured by a combination of plate tectonics which allows the crustal differentiation of heavy radioactive elements and their concentration as discrete minerals in granites, the strong erosive properties of surface water, and the sorting action of tides influenced by a single moon. Evidence that the inner planets of the Solar System are formed from relatively narrow accretion zones (Drake and Righter, 2002; Taylor $e t$ $a l ., 2003)$ suggests that we may not expect uranium/thorium concentrations to be at Earth levels in all rocky planets, although their budget on Venus may be similar to that on Earth (Taylor, 1999). The lack of plate tectonics on Mars except perhaps in infancy (Kerr, 1998; Nimmo and Stevenson, 2000), and on other terrestrial planets, limits the potential for crustal differentiation. Nevertheless, uranium and thorium represent the main heat sources in long-lived planets (Wänke, 1981), and rocky planets of Earth size and larger in other star systems may be common enough for the surface concentration of radioactive minerals to be a consistent process.

\section{Conclusions}

Models involving the polymerization of organic molecules by cosmic irradiation have been developed for both the interstellar medium and planetary surfaces, including the Earth. However, mineral radioactivity should also be considered in models for polymerization and concentration of organic matter. Radioactivity in the Earth's crust has been invoked previously, in general terms, as a source of energy for prebiotic synthesis (Martell, 1972; Albarrán and Collins, 1998; Garzón and Garzón, 2001). This account specifically identifies radioactive mineral sands as a template for the fixation and concentration of organic molecules. There are several reasons to consider sands in particular:

(i) Radioactive minerals became available at the planetary surface very early in its history, before the first evidence for life.

(ii) Hydrodynamic sorting of sand is a mechanism by which radioactive mineral grains become concentrated.

(iii) Radioactive sands occur especially in shallow water sediments, where they would have the opportunity to interact with organic molecules in both water and the atmosphere. 
(iv) Upon burial, radioactive sands would remain available to interact with molecules such as methane diffusing upwards through the crust.

(v) The geological record shows much evidence for the accretion of organic coatings around radioactive sand grains, extending back to Archean times.

Several aspects of this model deserve further study, including the experimental precipitation of organic coatings around radioactive grains, and their organic geochemical analysis, and more observations of carbonaceous accretion in the Archean record. Nevertheless, the current analysis indicates that on rocky planets with surface water, mineral radioactivity is likely to be a viable mechanism for the fixation and concentration of organic molecules.

\section{Acknowledgements}

I am grateful to two anonymous reviewers and A. W. Schwartz for their critical comments. J. B. Fulton kindly prepared Figure 1.

\section{References}

Albarrán, G. and Collins, C. H.: 1998, Radiolysis of Carbonates and Related Organic Systems $3.8 \times$ $10^{9}$ Years Ago, Viva Origino 26, 117-126.

Albarrán, G., Collins, K. E. and Collins, C. H.: 1987, Formation of Organic Products in SelfRadiolyzed Calcium Carbonate, J. Mol. Evol. 25, 12-14.

Ali, M. A., Krishnan, S. and Banerjee, D. C.: 2001, Beach and Inland Heavy Mineral Sand Investigations and Deposits in India - An Overview, Expl. Res. Atomic Mins., 13.

Bernstein, M. P., Allamandola, L. J. and Sanford, S. A.: 1997, Complex Organics in Laboratory Simulations of Interstellar/Cometary Ices, Adv. Space Res. 19, 19991-19998.

Bernstein, M. P., Sanford, S. A., Allamandola, L. J., Gillette, J. S., Clemett, S. J. and Zare, R. A.: 1999, UV Irradiation of Polycyclic Aromatic Hydrocarbons in Ices: Production of Alcohols, Quinones, and Ethers, Science 283, 1135-1138.

Bernstein, M. P., Dworkin, J. P., Sandford, S. A., Cooper, G. W. and Allamondola, L. J.: 2002, Racemic Amino Acids from the Ultraviolet Photolysis of Interstellar Ice Analogues, Nature 416, 401-403.

Bonnamy, S., Oberlin, A. and Trichet, J.: 1982, Two Examples of Uranium Associated with Organic Matter, Org. Geochem. 4, 53-61.

Buick, R., Rasmussen, B. and Krapez, B.: 1998, Archean Oil: Evidence for Extensive Hydrocarbon Generation and Migration 2.5-3.5 Ga, Amer. Assoc. Petrol. Geol. Bull. 82, 50-69.

Caffrey, J. M. and Allen, A. O.: 1958, Radiolysis of Pentane Adsorbed on Mineral Solids, J. Phys. Chem. 62, 33-37.

Catling, D. C.: 1999, A Chemical Model for Evaporites on Early Mars: Possible Sedimentary Tracers of the Early Climate and Implications for Exploration, J. Geophys. Res. 104, 16453-16469.

Charlesby, A.: 1987, Radiation Chemistry of Polymers, in Farhataziz and M. A. J. Rogers (eds.), Radiation Chemistry - Principles and Applications, VCH, New York, pp. 451-475.

Chyba, C. F.: 2000, Energy for Microbial Life on Europa, Nature 403, 381-382.

Chyba, C. F. and Phillips, C. B.: 2001, Possible Ecosystems and the Search for Life on Europa, Proc. Nat. Acad. Sci. 98, 801-804. 
Chyba, C. F. and Sagan, C.: 1992, Endogenous Production, Exogenous Delivery and Impact-Shock Synthesis of Organic Molecules: An Inventory for the Origins of Life, Nature 355, 125-132.

Colombo, U., Denti, E. and Sironi, G.: 1964, A Geochemical Investigation upon the Effects of Ionizing Radiation on Hydrocarbons, J. Inst. Petrol. 50, 228-237.

Cooper, J. F., Johnson, R. E., Mauk, B. H., Garrett, H. B. and Gehrels, N.: 2001, Energetic Ion and Electron Irradiation of the Icy Galilean Satellites, Icarus 149, 133-159.

Coppens, R. and Mayanda, M.: 1969, Sur la presence d'uraninite dans le sable de la plage de Quiberon (Morbihan), Comptes Rendus Acad. Sc. Paris, Ser. D. 268, 1016-1018.

Daulton, T. L. and Ozima, M.: 1996, Radiation-Induced Diamond Formation in Uranium-Rich Carbonaceous Materials, Science 271, 1260-1263.

Drake, M. J. and Righter, K.: 2002, Determining the Composition of the Earth, Nature 416, 39-44.

Ehrenfreund, P., Irvine, W., Becker, L., Blank, J., Brucato, J. R., Colangeli, L., Derenne, S., Despois, D., Dutrey, A., Fraaije, H., Lazcano, A., Owen, T., Robert, F. and International Space Science Institute ISSI-Team: 2002, Astrophysical and Astrochemical Insights into the Origin of Life, Rep. Prog. Phys. 65, 1427-1487.

Eisenbud, M. and Gesell, T.: 1997, Environmental Radioactivity, 4th Edition, Academic Press, London, 656 pp.

Fedo, C. M. and Whitehouse, M. J.: 2002, Metasomatic Origin of Quartz-Pyroxene Rock, Akilia, Greenland, and Implications for Earth's Earliest Life, Science 296, 1448-1452.

Forbes, P., Landais, P., Bertrand, P., Brosse, E., Espitalie, J. and Yahaya, M.: 1988, Chemical Transformations of Type-III Organic Matter Associated with the Akouta Uranium Deposit (Niger): Geological Implications, Chem. Geol. 71, 267-282.

Forster, L., Forster, P., Lutz-Bonengel, S., Willkomm, H. and Brinkmann, B.: 2002, Natural Radioactivity and Human Mitochondrial DNA Mutations, Proc. Nat. Acad. Sci. 99, 13950-13954.

Frankel, C: 1996, Volcanoes of the Solar System, Cambridge University Press, Cambridge, 232 pp.

Garzón, L. and Garzón, M. L.: 2001, Radioactivity as a Significant Energy Source in Prebiotic Synthesis, Origins Life Evol. Biosph. 31, 3-13.

Gindy, A. R.: 1961, Radioactivity in Monazite, Zircon and 'Radioactive Black' Grains in Blacksands of Rosetta, Egypt, Econ. Geol. 56, 436-441.

Glover, J. E.: 1992, Sediments of Early Archaean Coastal Plains: A Possible Environment for the Origin of Life, Precamb. Res. 56, 159-166.

Hamby, D. M. and Tynybekov, A. K.: 2002, Uranium, Thorium, and Potassium in Soils along the Shore of Lake Issyk-Kyol in the Kyrghyz Republic, Env. Monit. Assess. 73, 101-108.

Heckl, W. M.: 2002, Molecular Self-Assembly and the Origin of Life, in G. Horneck and C. Baumstark-Khan (eds.), Astrobiology, Springer, Berlin, pp. 361-372.

Holm, N. G. and Charlou, J. L.: 2001, Initial Indications of Abiotic Formation of Hydrocarbons in the Rainbow Ultramafic Hydrothermal System, Mid-Atlantic Ridge, Earth Planet. Sci. Letts. 191, 1-8.

Hung B. V., Dueng, P. V., Dien, P. Q. and Quang, N. H.: 1993, Natural Radiation in Mineral Sands Deposits in Vietnam and Problem of Radiological Protection, Radiation Protection in Australia 11, 174-176.

Jiang, T., Hayata, I., Wang, C., Nakai, S., Yao, S., Yuan, Y., Dai, L., Liu, Q., Chen, D., Wei, L. and Sugahara, T.: 2000, Dose-Effect Relationship of Dicentric and Ring Chromosomes in Lymphocytes of Individuals Living in the High Background Radiation Areas in China, J. Radiation Res. 41, S63-S68.

Kelley, D. S.: 1996, Methane-Rich Fluids in the Oceanic Crust, J. Geophys. Res. 101, 2943-2962.

Kerr, R. A.: 1998, Signs of Plate Tectonics on an Infant Mars, Science 279, 1605-1607.

Khare, B. N., Sagan, C., Thompson, W. R., Arakawa, E. T. and Votaw, P.: 1987, Solid Hydrocarbon Aerosols Produced in Simulated Uranian and Neptunian Stratospheres, J. Geophys. Res. 92, 15067-15082. 
Landais, P., Connan, J., Dereppe, J. M., George, E., Meunier, J. D., Monthioux, M., Pagel, M., Pironon, J. and Poty, B.: 1987, Alterations of Organic Matter: A Clue for Uranium Ore Genesis, Uranium 3, 307-342.

Landais, P., Dubessy, J., Dereppe, J-M. and Philp, R. P.: 1993, Characterization of Graphite Alteration and Bitumen Genesis in the Cigar Lake Deposit (Saskatchewan, Canada), Can. J. Earth Sci. 30, $743-753$.

Lasaga, A. C., Holland, H. D. and Dwyer, M. J.: 1971, Primordial Oil Slick, Science 174, 53-55.

Levine, J. S., Augustsson, T. R. and Natarajan, M.: 1982, The Prebiological Paleoatmosphere: Stability and Composition, Origins Life Evol. Biosp. 12, 245-259.

Liebenberg, W. R.: 1955, The Occurrence and Origin of Gold and Radioactive Minerals in the Witwatersrand System, the Dominion Reef, the Ventersdorp Contact Reef, and the Black Reef, Trans. Geol. Soc. S. Afr. 58, 101-223.

Lowe, D. R.: 1994, Early Environments: Constraints and Opportunities for Early Evolution, in S. Bengtson (ed.), Early Life on Earth, Nobel Symposium No. 84, Columbia University Press, pp. 24-35.

Maas, R., Kinny, P. D., Williams, I. S., Froude, D. O. and Compston, W.: 1992, The Earth's Earliest Known Crust: A Geochronological and Geochemical Study of 3900-4200 Ma Old Zircons from Mt. Narryer and Jack Hills, Western Australia, Geochim. Cosmochim. Acta 56, 1281-1300.

Maas, R. and McCulloch, M. T.: 1991, The Provenance of Archean Clastic Metasediments in the Narryer Gneiss Complex, Western Australia: Trace Element Geochemistry, Nd Isotopes, and U-Pb Ages of Detrital Zircons, Geochim. Cosmochim. Acta 46, 1915-1932.

McCord, T. B., Carlson, R. W., Smythe, W. D., Hansen, G. B., Clark, R. N., Hibbits, C. A., Fanale, F. P., Granahan, J. C., Segura, M., Matson, D. L., Johnson, T. V. and Martin, P. D.: 1997, Organics and other Molecules in the Surfaces of Callisto and Ganymede, Science 278, 271-275.

McCready, A. J., Stumpfl, E. F. and Melcher, F.: 2003, U/Th-Rich Bitumen in Archean Granites and Palaeoproterozoic Metasediments, Rum Jungle Mineral Field, Australia: Implications for Mineralizing Fluids, Geofluids 3, 147-159.

McLennan, S. M.: 2001, Crustal Heat Production and the Thermal Evolution of Mars, Geophys. Res. Letts. 28, 4019-4022.

Malanca, A., de Pieri, R. and Gazzola, A.: 1998, Radiogenic Heavy Minerals in Brazilian Beach Sand, J. Radioanal. Nucl. Chem. 230, 257-260.

Malanca, A., Repetti, M. and Gazzola, A.: 1995, A Radiological Investigation on the Monazite Sands of the Atlantic Brazilian Shore, Nucl. Geophys. 9, 453-459.

Malin, M. C. and Edgett, K. S.: 2000, Evidence for Recent Groundwater Seepage and Surface Runoff on Mars, Science 288, 2330-2335.

Manning, C. E., Mojzsis, S. J., Harrison, T. M. and Caciagli, N.: 2001, Geology and Age of Supracrustal Rocks, Akilia Island, Greenland: New Evidence for a $>3.83$ Ga Origin of Life, Astrobiology 1, 402-403.

Martell, E. A.: 1992, Radionuclide-Induced Evolution of DNA and the Origin of Life, J. Mol. Evol. 35, 346-355.

Mileikowsky, C., Cucinotta, F. A., Wilson, J. W., Gladman, B., Horneck, G., Lindegren, L., Melosh, J., Rickman, H., Valtonen, M. and Zheng, J. Q.: 2000, Natural Transfer of Viable Microbes in Space. 1. From Mars to Earth and Earth to Mars, Icarus 145, 391-427.

Miller, S. L. and Urey, H. C.: 1959, Organic Compound Synthesis on the Primitive Earth, Science 130, 245-251.

Miller, S. L., Urey, H. C. and Oró, J.: 1976, Origin of Organic Compounds on the Primitive Earth and in Meteorites, J. Mol. Evol. 9, 59-72.

Mojzsis, S. J., Arrhenius, G., McKeegan, K. D., Harrison, T. M., Nutman, A. P. and Friend, C. R. L.: 1996, Evidence for Life on Earth before 3,800 Million Years Ago, Nature 384, 55-59.

Nilson, F. P. R.: 2002, Possible Impact of a Primordial Oil Slick on Atmospheric and Chemical Evolution, Origins Life Evol. Biosph. 32, 247-253. 
Nimmo, F. and Stevenson, D. J.: 2000, Influence of Early Plate Tectonics on the Thermal Evolution and Magnetic Field of Mars, J. Geophys. Res. 105, 11969-11979.

Nuth, J. A. and Allen, J. E.: 1992, Supernovae as Sources of Interstellar Diamonds, Astrophys. Space Sci. 196, 117-123.

Nutman, A. P., Allaart, J. H., Bridgwater, D., Dimroth, E. and Rosing, M.: 1984, Stratigraphic and Geochemical Evidence for the Depositional Environment of the Early Archaean Isua Supracrustal Belt, Southern West Greenland, Precamb. Res. 25, 365-396.

Ozima, M. and Tatsumoto, M.: 1997, Radiation-Induced Diamond Crystallization: Origin of Carbonados and its Implications on Meteorite Nano-Diamonds, Geochim. Cosmochim. Acta 61, 369-376.

Parnell, J.: 1988, Metal Enrichments in Solid Bitumens, Mineral. Deposita 23, 191-199.

Parnell, J.: 1996a, Alteration of Crystalline Basement Rocks by Hydrocarbon-Bearing Fluids: Moinian of Ross-shire, Scotland, Lithos 37, 281-292.

Parnell, J.: 1996b, Petrographic Relationships between Mineral Phases and Bitumen in the Oklo Proterozoic Natural Fission Reactors, Gabon, Mineral. Mag. 60, 581-593.

Parnell, J., Monson, B. and Tosswill, R. J.: 1990, Petrography of Thoriferous Hydrocarbon Nodules in Sandstones, and their Significance for Petroleum Exploration, J. Geol. Soc. Lond. 147, 837842.

Peck, W. H., Valley, J. W., Wilde, S. A. and Graham, C. M.: 2001, Oxygen Isotope Ratios and Rare Earth Elements in 3.3 to $4.4 \mathrm{Ga}$ Zircons: Ion Microprobe Evidence for High $\delta^{18} \mathrm{O}$ Continental Crust and Oceans in the Early Archean, Geochim. Cosmochim. Acta 65, 4215-4229.

Penkov, V. F.: 1980, Genetic Relationship between Uraniferous Bitumens and Petroleum-Like Substances, Doklady Acad. Nauk SSSR 255, 186-189.

Rasmussen, B. and Buick, R.: 2000, Oily Old Ores: Evidence for Hydrothermal Petroleum Generation in an Archean Volcanogenic Massive Sulphide Deposit, Geology 28, 731-734.

Rasmussen, B., Glover, J. E. and Alexander, R.: 1989, Hydrocarbon Rims on Monazites in PermianTriassic Arenites, Northern Perth Basin, Western Australia: Pointers to the Former Presence of Oil, Geology 17, 115-118.

Rigali, M. J. and Nagy, B.: 1997, Organic Free Radicals and Micropores in Solid Graphitic Carbonaceous Matter at the Oklo Natural Fission Reactors, Gabon, Geochim. Cosmochim. Acta 61, $357-368$

Robb, L. J., Charlesworth, E. G., Drennan, G. R., Gibson, R. L. and Tongu, E. L.: 1997, TectonoMetamorphic Setting and Paragenetic Sequence of Au-U Mineralization in the Archaean Witwatersrand Basin, South Africa, Austr. J. Earth Sci. 44, 353-371.

Robb, L. J., Landais, P., Meyer, F. M. and Davis, D. W.: 1994, Nodular Organic Matter in Granites; Implications for the Origin of 'Kerogen' in the Witwatersrand Basin, South Africa, Explor. Mining Geol. 3, 219-230.

Saager, R., Utter, T. and Meyer, M.: 1982, Pre-Witwatersrand and Witwatersrand Conglomerates in South Africa: A Mineralogical Comparison and Bearings on the Genesis of Gold-Uranium Placers, in G. C. Amstutz, A. El Goresy, G. Frenzel, C. Kluth, G. Moh, A. Wauschkuhn and R. A. Zimmermann (eds.), Ore Genesis: The State of the Art, Springer, Berlin, pp. 38-56.

Sagan, C. and Chyba, C.: 1997, The Early Faint Sun Paradox: Organic Shielding of Ultraviolet-Labile Greenhouse Gases, Science 276, 1217-1221.

Simpson, P. R. and Bowles, J. F. W.: 1981, Detrital Uraninite and Pyrite: Are they Evidence for a Reducing Atmosphere?, U.S. Geol. Surv. Prof. Paper 1161, S1-S12.

Smith, J. V., Arnold, F. P., Parsons, I. and Lee, M. R.: 1999, Biochemical Evolution III: Polymerization on Organophilic Silica-Rich Surfaces, Crystal-Chemical Modelling, Formation of First Cells, and Geological Clues, Proc. Natl. Acad. Sci. U.S.A. 96, 3479-3485.

Spinks, J. W. T. and Woods, R. J.: 1990, An Introduction to Radiation Chemistry, 3rd Edition, WileyInterscience, New York, 504 pp.

Stevenson, D. L.: 1999, Life-Sustaining Planets in Interstellar Space?, Nature 400, 32. 
Strazzulla, G., Calcagno, L. and Foti, G.: 1984, Buildup of Carbonaceous Material by Fast Protons on Pluto and Triton, Astron. Astrophys. 140, 441-444.

Strazzulla, G. and Palumbo, M. E.: 1998, Evolution of Icy Surfaces: An Experimental Approach, Planet. Space Sci. 46, 1339-1348.

Taylor, G. J., Boynton, W., Hamara, D., Kerry, K., Janes, D., Keller, J., Feldman, W., Prettyman, T., Reedy, R., Brückner, J., Wänke, H., Evans, L., Starr, R., Squyres, S., Karunatillake, S., Gasnault, O. and Odyssey GRS Team: 2003, Evolution of the Martian Crust: Evidence from Preliminary Potassium and Thorium Measurements by Mars Odyssey Gamma-Ray Spectrometer, Lunar and Planetary Science, XXXIV, Abstract 2004.

Taylor, S. R.: 1999, On the Difficulties of Making Earth-Like Planets, Meteor. Planet, Sci. 34, 317 329.

Ueno, Y., Yurimoto, H., Yoshioka, H., Komiya, T. and Maruyama, S.: 2002, Ion Microprobe Analysis of Graphite from ca. 3.8 Ga Metasediments, Isua Supracrustal Belt, West Greenland: Relationship between Metamorphism and Carbon Isotopic Composition, Geochim. Cosmochim. Acta 66, 1257-1268.

Valley, J. W., Peck, W. H., King, E. M. and Wilde, S. A.: 2002, A Cool Early Earth, Geology 30, 351-354.

Van Zuilen, M. A., Valley, J. W., Spicuzza, M. J., Lepland, A. and Arrhenius, G.: 2002, ApatiteGraphite in Quartz-Pyroxene Rock from Akilia Island; Primary Biogenic Origin Questioned by Oxygen Isotope Evidence, Amer. Geophys. Union, Fall Meeting 2002, Abstract P71C-0474.

Walker, J. C. G.: 1985, Carbon Dioxide on the Early Earth, Origins Life Evol. Biosph. 16, 117.

Wänke, H.: 1981, Constitution of Terrestrial Planets, Phil. Trans. R. Soc. Lond. 303, 287-302.

Wilde, S. A., Valley, J. W., Peck, W. H. and Graham, C. M.: 2001, Evidence from Detrital Zircons for the Existence of Continental Crust and Oceans on the Earth 4.4 Gyr Ago, Nature 409, 175-178. 